(c) 2018 - ISSN 1807-2577

\title{
LL-37 and hBD-2 in the gingival crevicular fluid of smokers and nonsmokers with periodontitis
}

\author{
LL-37 e hBD-2 no fluido crevicular de fumantes e não fumantes com \\ periodontite
}

\author{
Alessandra Barreto LOPES ${ }^{a}$ (1) , Natália Helena COLOMBO ${ }^{b}$ (i) , Naida Zanini ASSEM ${ }^{a}$ (D),

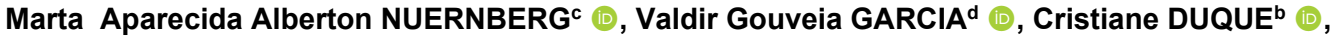 \\ Leticia Helena THEODORO ${ }^{a *}$ (1) \\ a UNESP - Universidade Estadual Paulista, Faculdade de Odontologia de Araçatuba, Departamento de Diagnóstico e \\ Cirurgia, Araçatuba, SP, Brasil \\ ${ }^{\mathrm{b}}$ UNESP - Universidade Estadual Paulista, Faculdade de Odontologia de Araçatuba, Departamento de Odontologia \\ Preventiva e Restauradora, Araçatuba, SP, Brasil \\ ${ }^{c}$ CEUUN - Centro Universitário Unisep, Campus Francisco Beltrão, Francisco Beltrão, PR, Brasil

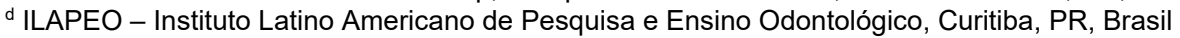

\begin{abstract}
How to cite: Lopes AB, Colombo NH, Assem NZ, Nuernberg MAA, Garcia VG, Duque C, et al. LL-37 and hBD-2 in the gingival crevicular fluid of smokers and nonsmokers with periodontitis. Rev Odontol UNESP. 2021;50:e20210056. https://doi.org/10.1590/1807-2577.05621
\end{abstract}

\begin{abstract}
Resumo
Introdução: A associação entre tabagismo e doença periodontal tem sido descrito em estudos clínicos e epidemiológicos. Objetivo: 0 objetivo deste estudo foi comparar os níveis de LL-37 e beta defensina-2 (hBD-2) no fluido crevicular de pacientes com periodontite generalizada fumantes (F) e não fumantes (NF). Material e método: Um total de 35 pacientes com periodontite generalizada estágios III e IV, $15 \mathrm{NF}$ (11 mulheres, 4 homens) e $20 \mathrm{~F}$ ( 7 mulheres e 13 homens), foram incluídos no estudo. Os parâmetros clínicos avaliados foram sangramento à sondagem (SS), profundidade de sondagem (PS) e nível de inserção clínica (NIC). Ensaios imuno enzimáticos foram realizados para quantificar os níveis de LL-37 e hBD-2 no fluido crevicular das gengivas dos pacientes. Resultado: Os resultados foram analisados estatisticamente, com nível de significância de $5 \%$. Em relação aos parâmetros clínicos periodontais, não foi observada diferença estatisticamente significativa para SS e PS comparando os grupos F e NF. Houve maior NIC nos pacientes do grupo F, quando comparados ao grupo NF ( $p=0,0095)$. Não houve diferença estatisticamente significativa entre os níveis de LL-37 e hBD-2 quando comparados os grupos $\mathrm{F}$ e NF ( $p>0,05)$. Conclusão: Concluiu-se que os fumantes apresentam maior perda de inserção clínica do que os não fumantes, mas o tabagismo não influenciou nos níveis de LL-37 e hBD-2 do fluido gengival em indivíduos com periodontite.
\end{abstract}

Descritores: Periodontite; peptídeos antimicrobianos; fumantes.

\begin{abstract}
Introduction: The association between smoking and periodontal diseases has been described in clinical and epidemiological studies. Objective: The aim of this study was to compare the LL-37 and human $\beta$-defensin-2 (hBD-2) levels in crevicular fluid of patients with generalized periodontitis in smokers (S) and nonsmokers (NS). Material and method: A total of 35 patients with generalized periodontitis stages III and IV, 15 NS (11 female, 4 male) and $20 \mathrm{~S}$ (7 female and 13 male), were included in the study. The evaluated clinical parameters were bleeding on probing (BOP), probing depth (PD) and clinical attachment level (CAL). Enzyme-linked immunosorbent assays were performed to quantify the LL-37 and hBD-2 levels in the gingival crevicular fluid of these patients. The results were analyzed statistically with the level of significance set at 5\%. Result: In relation to periodontal clinical parameters, no statistically significant difference was observed for BOP and PD between groups $S$ and NS. There was a higher CAL in the $S$ group than in the NS group $(p=0.0095)$. There was no statistically significant difference between the levels of LL-37 and hBD-2 when
\end{abstract}


comparing groups S and NS ( $\mathrm{p}>0.05)$. Conclusion: It was concluded that smokers have a higher clinical attachment loss than nonsmokers, but that smoking did not influence the levels of LL-37 and hBD-2 in the gingival crevicular fluid in periodontitis.

Descriptors: Periodontitis; antimicrobial peptides; smoking.

\section{INTRODUCTION}

Periodontitis is defined as a multifactorial chronic inflammatory disease associated with a dysbiotic biofilm, characterized by the progressive destruction of supporting periodontal tissues ${ }^{1}$. Dysbiosis results from the process of microbial succession mediated by inflammation in periodontitis, in which species associated with the disease appear temporally and spatially in the periodontal pocket ${ }^{2}$. The development and severity of periodontal disease depends on a dynamic balance between bacteria associated with plaque, the immune status of the individual, genetic and environmental factors, oral hygiene habits, smoking and alcohol. These factors can cause increased susceptibility to the disease and also affect/regulate the host's immune response to the bacteria ${ }^{3}$.

The association between smoking and periodontal health has been described in clinical and epidemiological studies ${ }^{4}$. Cigarette smoking has also been demonstrated as a major risk factor in the prevalence, extent and severity of periodontal disease, and studies have suggested that smoking increases between two to six times the risk of periodontal disease ${ }^{5}$. Environmental risk factors, such as smoking, promote alterations in the immune and inflammatory system and have a negative impact on periodontitis ${ }^{6}$. A greater clinical attachment loss and more rapid progression of periodontal breakdown has been observed in smokers, compared to non smokers ${ }^{7}$. The relationship between exposure to time - years of smoking exposure - and periodontal damage is dose-dependent ${ }^{7}$. Increased cigarette consumption intensifies the severity of periodontal disease and the effect becomes clinically evident at $>10$ cigarettes / day ${ }^{8}$. The mechanism of organism defense is based on innate and adaptive immunity ${ }^{9}$. The secretion of antimicrobial peptides, such as defensins and cathelicidin LL-37, is an important stage of the innate defense mechanism ${ }^{10}$.

Human beta-defensins (hBDs) are small cationic antimicrobial peptides, with a group of cysteine residues, which can eliminate a wide range of Gram-positive and Gram-negative bacteria, disrupt the integrity of the cell membrane of bacteria, and stimulate production of antigen presenting cells against a wide spectrum of bacteria11. In human gingival tissue, human beta-defensin -1 (hBD-1) and human beta-defensin -2 (hBD-2) are peptides expressed in normal non-inflamed tissue, but also can be found within the sulcular epithelium during inflammation stages, and in higher levels in the gingival margin and plaque formation sites ${ }^{12}$. From that moment on, hBD-2 are also expressed on monocytes and alveolar macrophages that have been stimulated by proinflammatory cytokines such as interleukin-1 $\beta$ and a tumor necrosis factor ${ }^{13}$. LL-37 is an important antimicrobial peptide that belongs to cathelicidins group, containing 37 amino acids, and is derived by enzymatic cleavage of a precursor protein of $18 \mathrm{kDa}, \mathrm{HCAP} 18^{14}$. LL-37 is a multifunctional modulator of innate immunity involving the antibacterial function ${ }^{15}$, the stimulation of angiogenesis ${ }^{16}$, skin healing and chemotaxis of inflammatory and the immune system cells ${ }^{17}$. Studies have shown that the levels of LL-37 in the gingival crevicular fluid are increased during chronic periodontitis ${ }^{18}$. LL-37 levels are higher in the gingival crevicular fluid of inflamed sites when compared with healthy sites in the same individual ${ }^{19}$, and LL-37 deficiency has been directly implicated in the development of periodontitis ${ }^{20}$. Therefore, the objective of this study was to compare the levels of LL-37 and hBD-2 in the gingival crevicular fluid of smokers and nonsmokers with generalized periodontitis. 


\section{MATERIAL AND METHOD}

\section{Patient Selection}

Patients from the Periodontal Clinic, School of Dentistry, Araçatuba, São Paulo State University (UNESP), were selected in 2013 to participate in this study. The study was approved by the Human Ethics Research Committee of Araçatuba, UNESP (CAAE 05519412.5.0000.5420). After all patients had signed written consent, their medical and dental histories were taken. The criteria of inclusion were: patients aged $\geq 30$ and $\leq 70$ years ${ }^{21}$, diagnosis of generalized periodontitis stages III and IV, with a minimum of 6 teeth and at least one site with probing depth (PD) and clinical attachment level (CAL) $\geq 5 \mathrm{~mm}$, and at least $30 \%$ of sites with PD and CAL $\geq 4 \mathrm{~mm}$ and bleeding on probing (BOP) ${ }^{22}$; in the case of patients from the $S$ group, they would have to smoke more than 10 cigarettes per day. The exclusion criteria were: medical disorders that required antibiotic prophylaxis; having received periodontal treatment in the last 6 months; consumed medicine that affects the periodontal tissue in the last 6 months (antibiotics, anti-inflammatories, anticonvulsants, immunosuppressant or calcium channel blockers); pregnancy; undergoing orthodontic treatment; and a presence of metabolic disorders like diabetes, immunological disorders, alcoholism or use of illicit drugs.

\section{Clinical Parameters}

A single examiner (ABL), calibrated before the trial, performed all clinical exams. Each patient was submitted to a clinical periodontal exams where the following parameters were evaluated: BOP, PD and CAL. PD and CAL were obtained at six sites of every tooth ${ }^{23,24}$. A periodontal probe with 1-mm marks was used (PCPUNC-15, Hu-Friedy, Chicago, IL, USA). Periapical radiographs of all teeth were obtained for all patients. Means and standard deviations of PD and CAL were calculated for each participant for all sites in the mouth. The categorical data of BOP were transformed into percentages, and averages and standard deviations of the whole mouth were obtained.

\section{Examiner Calibration}

The calibration procedures of a blind examiner for the clinical trials in the respective patients were performed. For this purpose, one hundred and twenty sites with probing depth $\geq 5 \mathrm{~mm}$ were randomly selected in 6 patients (20 sites per patient). These sites were evaluated for probing depth on two separate occasions at 7 days intervals. For the calibration of the examiner, the data were submitted to the Kappa agreement test, obtaining a value of 0.85 , which represents a significant intra-examiner agreement ${ }^{24}$.

\section{Subgingival Sample Collection for Immunological Analysis}

Samples of subgingival biofilm were obtained from one moderate (PD $>4$ and $\leq 6 \mathrm{~mm}$ ) and one deep pocket (PD $\geq 7 \mathrm{~mm}$ ) of each participant. Samples for immunological analysis were collected after the removal of supragingival plaque, and the selected sites were isolated with cotton rolls and gently air-dried. Subgingival plaque was collected using sterile paper points (\# 30; Tanari, Manacapuru, AM, Brazil) that were inserted into the base of the pocket for 30 seconds. The paper points were immediately placed in sterile microtubes containing $500 \mu \mathrm{l}$ of sterilized PBS (phosphate - buffered saline) solution and stored at $-80^{\circ} \mathrm{C}$. 


\section{Enzyme-linked Immunosorbent Assay for LL-37 and hBD-2 Measurements}

The concentration of LL-37 and hBD-2 in the gingival crevicular fluid samples was determined using commercially available enzyme-linked immunosorbent assay (ELISA) kits, specific for each peptide (MyBioSource, Inc. San Diego, CA, USA), in accordance with the manufacturer's instructions.

\section{Statistical Analysis}

Data were analyzed using Bioestat 5.0 (BioEstat 5.0, BioEstat Software, Manaus, AM, Brazil). The normality of data was analyzed using the Shapiro-Wilk test. Data from periodontal parameters were expressed as means and standard deviations, and groups were compared using a parametric test (Student $T$ test) at 5\% significance level. The comparison between patients in relation to age and BOP data was statistically analyzed using the nonparametric Mann-Whitney test. PD, CAL, LL-37 and hBD-2 levels were submitted to the Student T test.

\section{RESULT}

\section{Clinical and Demographic Data}

A total of 35 patients with periodontitis were included in this study, comprising 15 nonsmokers (NS) (11 female, 4 male age $46.7 \pm 8.9$ ) and 20 smokers (S) (7 female and 13 male age 49.9 \pm 4.9 ) . The average number of cigarettes smoked per day by patients in group S was $14.93 \pm 3.52$. No statistically significant difference was observed for BOP and PD between groups S and NS. There was a higher CAL in group $\mathrm{S}$ than in NS ( $p=0.0095)$ (Table 1$)$.

Table 1. Demographic characteristics and clinical periodontal parameters in Groups NS and S

\begin{tabular}{ccc}
\hline Variable & Group NS & Group S \\
\hline Number of patients(n) & 15 & 20 \\
Age (years) & $46.7 \pm 8.9$ & $49.2 \pm 4.9$ \\
Women, n (\%) & $11(73.3 \%)$ & $7(35 \%)$ \\
PD (mm) & $3.78 \pm 0.52$ & $3.99 \pm 0.42$ \\
CAL (mm) & $4.10 \pm 0.59$ & $4.56 \pm 0.43^{*}$ \\
BOP (\%) & $92.64 \pm 7.07$ & $89.03 \pm 8.75$ \\
\hline
\end{tabular}

*Statistically significant difference with NS group (Student T test; $\mathrm{p}<0.05$ ).

\section{Immunological Analysis}

There was no statistically significant difference between the levels of LL-37 and hBD-2, comparing patients in groups S and NS ( $>>0.05$; Figures 1 and 2). 


\section{LL-37}

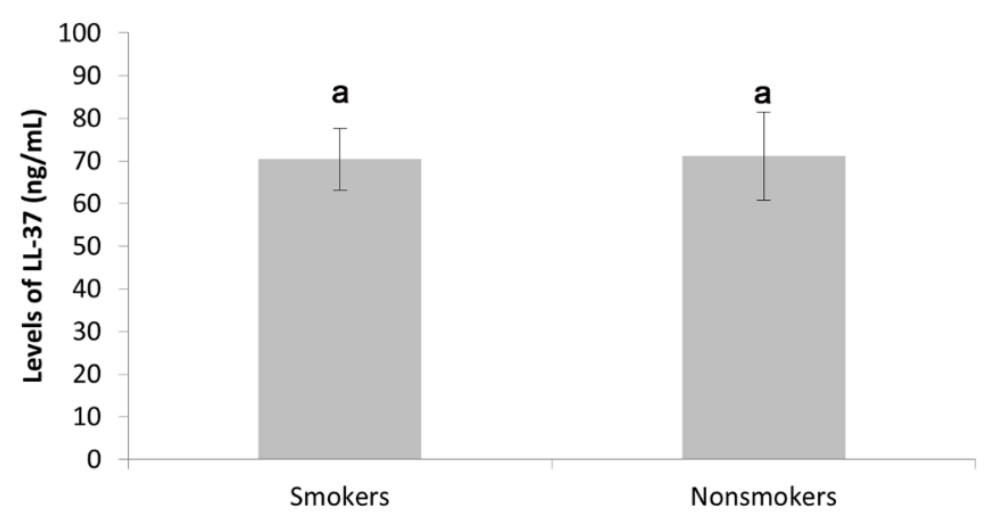

Figure 1. Levels of LL-37 in the gingival crevicular fluid of smokers and nonsmokers.

Equal letters show no difference between groups, according to Student $\mathrm{T}$ test, $\mathrm{p}<0.05$.

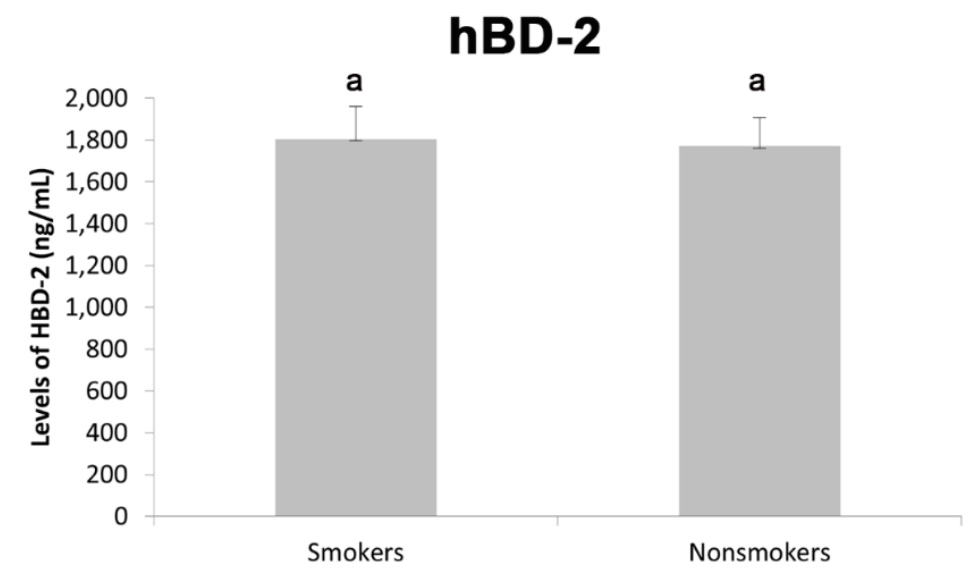

Figure 2. Levels of hBD-2 in the gingival crevicular fluid of smokers and nonsmokers.

Equal letters show no difference between groups, according to Student $\mathrm{T}$ test, $\mathrm{p}<0.05$.

\section{DISCUSSION}

In several studies, smokers showed greater PD than non-smokers ${ }^{25}$, or had greater CAL, increased bone loss, deeper periodontal pockets, than nonsmokers ${ }^{8,25}$. There was no statistically significant difference in most clinical parameters evaluated, or in the levels of LL-37 and hBD-2 between smoking and nonsmoking patients. However, a higher CAL was observed in smokers. The present results may be associated with the sample size, suggesting an insufficient sample to determine a statistically significant difference. New surveys, with a larger number of participants, can provide valuable information for a better understanding of the results found.

One study reported that the means of periodontal attachment loss associated with smoking were $3 \mathrm{~mm}$ or more in the age group 20-49 years ${ }^{26}$. Among those over 50 years, the means of periodontal attachment loss were $4 \mathrm{~mm}$ or more ${ }^{26}$. Longitudinal studies in smokers have reported that smokers are about two to five times more likely to have loss of periodontal attachment ${ }^{27}$ and bone $\operatorname{loss}^{28}$ than nonsmokers. 
Although the present study has set no difference between the groups in the BOP parameter, some studies have found that smokers exhibited significantly lower scores of BOP than nonsmokers ${ }^{29}$ in generalized forms of periodontitis. The aforementioned studies have reported that smoking leads to peripheral vasoconstriction caused by low chronic doses of nicotine, and that periodontal disease is often masked by the absence of classic signs of acute gingival inflammation, even though BOP may occur. There is a chronic reduction in blood and vascular flow confirming the reduction of the gingival bleeding ${ }^{30}$, which may affect the recognition of periodontal disease presence.

It has been found that periodontal infection and inflammation can affect the location and expression of antimicrobial peptides ${ }^{31}$. The relationship between the levels of antimicrobial peptides and the presence of periodontal disease remains controversial in the literature. In the present study no statistically significant differences were observed for LL-37 and hBD-2 levels when comparing groups of smokers and nonsmokers. Nevertheless, some researchers have demonstrated a downregulation in the expression of hBD-2 in smokers ${ }^{32}$, whereas others have reported a positive regulation of hBD-2 expression due to smoking33.

A previous study that examined the levels of HBD-1 and hBD-2 in healthy periodontal tissue and inflamed tissue in patients with gingivitis, aggressive periodontitis and chronic periodontitis, has reported that the expression of hBD-2 was higher in patients with chronic periodontitis than in the other groups ${ }^{34}$.

Similarly, other authors found a higher concentration of hBD-2 in the gingival crevicular fluid of patients with chronic periodontitis and in patients with chronic gingivitis than in healthy patients ${ }^{35}$. In another study, hBD-2 was higher in patients with chronic periodontitis than in patients with gingivitis or healthy individuals ${ }^{36}$. Conversely, some results showed that hBDs expression was lower in patients with chronic periodontitis ${ }^{37}$. The relationship between hBDs and periodontal pathogens has been also investigated ${ }^{36}$.

LL-37 is an important antimicrobial peptide, associated with the defense of periodontal tissues against microbial pathogens in the oral cavity ${ }^{38}$. LL-37 production is higher in inflamed gingival tissue than in healthy gingival tissue ${ }^{39}$. In a previous study, a higher level of LL-37 was found in the crevicular fluid of nonsmoking patients with chronic periodontitis, compared to nonsmokers ${ }^{40}$. In the present study, there is no statistical difference between the LL37 levels of smokers and nonsmokers. The results of another study that compared the salivary levels of LL-37 have shown that in healthy oral mucosa and in periodontal disease conditions there was a marked decrease in LL-37 levels in edentulous patients ${ }^{41}$. Due to the controversies seen in the findings of clinical studies, it is recommended that new clinical studies be conducted to assess the correlation between the degree of periodontitis and the presence of this peptide in smokers and nonsmokers. Further studies are also needed to fully understand the effects of smoking and nicotine, as well as of LL-37 and hBD-2 in periodontal diseases ${ }^{42}$.

\section{CONCLUSION}

According to our results, it was concluded that smokers have a higher clinical attachment loss than nonsmokers, but that smoking did not influence the levels of LL-37 and hBD-2 in the gingival crevicular fluid.

\section{REFERENCES}

1. Papapanou PN, Sanz M, Buduneli N, Dietrich T, Feres M, Fine DH, et al. Periodontitis: consensus report of workgroup 2 of the 2017 World Workshop on the classification of periodontal and peri-implant diseases and conditions. J Periodontol. 2018 Jun;89(Suppl 1):S173-82.

http://dx.doi.org/10.1002/JPER.17-0721. PMid:29926951. 
2. van Dyke TE, Bartold PM, Reynolds EC. The nexus between periodontal inflammation and dysbiosis. Front Immunol. 2020 Mar;11:511. http://dx.doi.org/10.3389/fimmu.2020.00511. PMid:32296429.

3. Darveau RP. Periodontitis: a polymicrobial disruption of host homeostasis. Nat Rev Microbiol. 2010 Jul;8(7):481-90. http://dx.doi.org/10.1038/nrmicro2337. PMid:20514045.

4. Bergström J. Periodontitis and smoking: an evidence-based appraisal. J Evid Based Dent Pract. 2006 Mar;6(1):33-41. http://dx.doi.org/10.1016/j.jebdp.2005.12.018. PMid:17138394.

5. Johannsen A, Susin C, Gustafsson A. Smoking and inflammation: evidence for a synergistic role in chronic disease. Periodontol 2000. 2014 Feb;64(1):111-26. http://dx.doi.org/10.1111/j.16000757.2012.00456.x. PMid:24320959.

6. Jepsen S, Caton JG, Albandar JM, Bissada NF, Bouchard P, Cortellini P, et al. Periodontal manifestations of systemic diseases and developmental and acquired conditions: consensus report of workgroup 3 of the 2017 World Workshop on the classification of periodontal and peri-implant diseases and conditions. J Periodontol. 2018 Jun;89(Suppl 1):S237-48. http://dx.doi.org/10.1002/JPER.17-0733. PMid:29926943.

7. Bergström J. Tobacco smoking and risk for periodontal disease. J Clin Periodontol. 2003;30(2):107-13. http://dx.doi.org/10.1034/j.1600-051X.2003.00272.x. PMid:12622851.

8. Grossi SG, Genco RJ, Machtet EE, Ho AW, Koch G, Dunford R, et al. Assessment of risk for periodontal disease. II. Risk indicators for alveolar bone loss. J Periodontol. 1995;66(1):23-9. http://dx.doi.org/10.1902/jop.1995.66.1.23. PMid:7891246.

9. Gorr SU. Antimicrobial peptides of the oral cavity. Periodontol 2000. 2009;51(1):152-80. http://dx.doi.org/10.1111/j.1600-0757.2009.00310.x. PMid:19878474.

10. Makeudom A, Kulpawaropas S, Montreekachon P, Khongkhunthian S, Sastraruji T, Pothacharoen $\mathrm{P}$, et al. Positive correlations between hCAP18/LL-37 and chondroitin sulphate levels in chronic periodontitis. J Clin Periodontol. 2014 Mar;41(3):252-61. http://dx.doi.org/10.1111/jcpe.12216. PMid:24372543.

11. Lu Q, Jin L, Darveau RP, Samaranayake LP. Expression of human beta-defensins-1 and -2 peptides in unresolved chronic periodontitis. J Periodontal Res. 2004 Aug;39(4):221-7. http://dx.doi.org/10.1111/j.1600-0765.2004.00727.x. PMid:15206914.

12. Dale BA, Krisanaprakornkit S. Defensin antimicrobial peptides in the oral cavity. J Oral Pathol Med. 2001 Jul;30(6):321-7. http://dx.doi.org/10.1034/j.1600-0714.2001.300601.x. PMid:11459317.

13. Duits LA, Ravensbergen B, Rademaker M, Hiemstra PS, Nibbering PH. Expression of beta-defensin 1 and 2 mRNA by human monocytes, macrophages and dendritic cells. Immunology. 2002 Aug;106(4):517-25. http://dx.doi.org/10.1046/j.1365-2567.2002.01430.x. PMid:12153515.

14. Kai-Larsen Y, Agerberth B. The role of the multifunctional peptide LL-37 in host defense. Front Biosci. 2008 May; 13:3760-7. http://dx.doi.org/10.2741/2964. PMid:18508470.

15. Cowland JB, Johnsen AH, Borregaard N. hCAP-18, a cathelin/pro-bactenecin-like protein of human neutrophil specific granules. FEBS Lett. 1995 Jul;368(1):173-6. http://dx.doi.org/10.1016/00145793(95)00634-L. PMid:7615076.

16. Koczulla R, von Degenfeld G, Kupatt C, Krötz F, Zahler S, Gloe T, et al. An angiogenic role for the human peptide antibiotic LL-37/hCAP-18. J Clin Invest. 2003 Jun;111(11):1665-72. http://dx.doi.org/10.1172/JCI17545. PMid:12782669.

17. Yang D, Chen Q, Schmidt AP, Anderson GM, Wang JM, Wooters J, et al. LL-37, the neutrophil granuleand epithelial cell-derived cathelicidin, utilizes formyl peptide receptor-like 1 (FPRL1) as a receptor to chemoattract human peripheral blood neutrophils, monocytes, and T cells. J Exp Med. 2000 Oct;192(7):1069-74. http://dx.doi.org/10.1084/jem.192.7.1069. PMid:11015447. 
18. Türkoğlu O, Emingil G, Kütükçüler N, Atilla G. Gingival crevicular fluid levels of cathelicidin LL-37 and interleukin-18 in patients with chronic periodontitis. J Periodontol. 2009 Jun;80(6):969-76. http://dx.doi.org/10.1902/jop.2009.080532. PMid:19485828.

19. Dommisch H, Vorderwülbecke S, Eberhard J, Steglich M, Jepsen S. SELDI-TOF-MS of gingival crevicular fluid--a methodological approach. Arch Oral Biol. 2009 Sep;54(9):803-9. http://dx.doi.org/10.1016/j.archoralbio.2009.05.011. PMid:19555922.

20. Pütsep K, Carlsson G, Boman HG, Andersson M. Deficiency of antibacterial peptides in patients with morbus Kostmann: an observation study. Lancet. 2002 Oct;360(9340):1144-9. http://dx.doi.org/10.1016/S0140-6736(02)11201-3. PMid:12387964.

21. Matarazzo F, Figueiredo LC, Cruz SE, Faveri M, Feres M. Clinical and microbiological benefits of systemic metronidazole and amoxicillin in the treatment of smokers with chronic periodontitis: a randomized placebo-controlled study. J Clin Periodontol. 2008 Oct;35(10):885-96. http://dx.doi.org/10.1111/j.1600-051X.2008.01304.x. PMid:18727657.

22. Armitage GC. Development of a classification system for periodontal diseases and conditions. Ann Periodontol. 1999 Dec;4(1):1-6. http://dx.doi.org/10.1902/annals.1999.4.1.1. PMid:10863370.

23. Cláudio MM, Nuernberg MAA, Rodrigues JVS, Belizário LCG, Batista JA, Duque C, et al. Effects of multiple sessions of antimicrobial photodynamic therapy (aPDT) in the treatment of periodontitis in patients with uncompensated type 2 diabetes: A randomized controlled clinical study. Photodiagn Photodiagnosis Photodyn Ther. 2021 Sep;35:102451. http://dx.doi.org/10.1016/j.pdpdt.2021.102451. PMid:34303029.

24. Theodoro LH, Lopes AB, Nuernberg MAA, Cláudio MM, Miessi DMJ, Alves MLF, et al. Comparison of repeated applications of aPDT with amoxicillin and metronidazole in the treatment of chronic periodontitis: a short-term study. J Photochem Photobiol B. 2017 Sep;174:364-9. http://dx.doi.org/10.1016/j.jphotobiol.2017.08.012. PMid:28863395.

25. Radvar M, Darby I, Polster A, Arashi M, Moeintaghavi A, Sohrabi K. Pattern of cigarette smoking effect on periodontal pocketing and attachment loss: a retrospective study. Int J Dent Hyg. 2011 Nov;9(4):291-5. http://dx.doi.org/10.1111/j.1601-5037.2010.00496.x. PMid:21356029.

26. Hyman JJ, Reid BC. Epidemiologic risk factors for periodontal attachment loss among adults in the United States. J Clin Periodontol. 2003 Mar;30(3):230-7. http://dx.doi.org/10.1034/j.1600051X.2003.00157.x. PMid:12631181.

27. Gilbert GH, Shelton BJ, Fisher MA. Forty-eight-month periodontal attachment loss incidence in a population-based cohort study: role of baseline status, incident tooth loss, and specific behavioral factors. J Periodontol. 2005 Jul;76(7):1161-70. http://dx.doi.org/10.1902/jop.2005.76.7.1161. PMid:16018760.

28. Baljoon M, Natto S, Bergström J. Long-term effect of smoking on vertical periodontal bone loss. J Clin Periodontol. 2005 Jul;32(7):789-97. http://dx.doi.org/10.1111/j.1600-051X.2005.00765.x. PMid:15966888.

29. Dietrich T, Bernimoulin JP, Glynn RJ. The effect of cigarette smoking on gingival bleeding. J Periodontol. 2004 Jan;75(1):16-22. http://dx.doi.org/10.1902/jop.2004.75.1.16. PMid:15025212.

30. Morozumi T, Kubota T, Sato T, Okuda K, Yoshie H. Smoking cessation increases gingival blood flow and gingival crevicular fluid. J Clin Periodontol. 2004 Apr;31(4):267-72. http://dx.doi.org/10.1111/j.1600051X.2004.00476.x. PMid:15016254.

31. Gursoy UK, Könönen E. Understanding the roles of gingival beta-defensins. J Oral Microbiol. 2012;4(1):15127. http://dx.doi.org/10.3402/jom.v4i0.15127. PMid:22389759.

32. Wolgin M, Liodakis S, Pries AR, Zakrzewicz A, Kielbassa AM. HBD-1 and hBD-2 expression in HaCaT keratinocytes stimulated with nicotine. Arch Oral Biol. 2012 Jun;57(6):814-9.

http://dx.doi.org/10.1016/j.archoralbio.2011.11.018. PMid:22209221. 
33. Nakamura S, Saitoh M, Yamazaki M, Nishimura M, Kurashige Y, Arakawa T, et al. Nicotine induces upregulated expression of beta defensin-2 via the p38MAPK pathway in the HaCaT human keratinocyte cell line. Med Mol Morphol. 2010 Dec;43(4):204-10. http://dx.doi.org/10.1007/s00795010-0493-4. PMid:21267696.

34. Yılmaz D, Güncü GN, Könönen E, Barış E, Çağlayan F, Gursoy UK. Overexpressions of hBD-2, hBD-3, and hCAP18/LL-37 in gingiva of diabetics with periodontitis. Immunobiology. 2015 Nov;220(11):1219-26. http://dx.doi.org/10.1016/j.imbio.2015.06.013. PMid:26092093.

35. Yong X, Chen Y, Tao R, Zeng Q, Liu Z, Jiang L, et al. Periodontopathogens and human $\beta$-defensin-2 expression in gingival crevicular fluid from patients with periodontal disease in Guangxi, China. J Periodontal Res. 2015 Jun;50(3):403-10. http://dx.doi.org/10.1111/jre.12220. PMid:25065393.

36. Pereira AL, Franco GC, Cortelli SC, Aquino DR, Costa FO, Raslan AS, et al. Influence of periodontal status and periodontopathogens on levels of oral human $\beta$-defensin-2 in saliva. J Periodontol. 2013 Oct;84(10):1445-53. http://dx.doi.org/10.1902/jop.2012.120321. PMid:23173827.

37. Brancatisano FL, Maisetta G, Barsotti F, Esin S, Miceli M, Gabriele M, et al. Reduced human beta defensin 3 in individuals with periodontal disease. J Dent Res. 2011 Feb;90(2):241-5. http://dx.doi.org/10.1177/0022034510385686. PMid:21148015.

38. Puklo M, Guentsch A, Hiemstra PS, Eick S, Potempa J. Analysis of neutrophil-derived antimicrobial peptides in gingival crevicular fluid suggests importance of cathelicidin LL-37 in the innate immune response against periodontogenic bacteria. Oral Microbiol Immunol. 2008 Aug;23(4):328-35. http://dx.doi.org/10.1111/j.1399-302X.2008.00433.x. PMid:18582333.

39. Hosokawa I, Hosokawa Y, Komatsuzawa H, Goncalves RB, Karimbux N, Napimoga MH, et al. Innate immune peptide LL-37 displays distinct expression pattern from beta-defensins in inflamed gingival tissue. Clin Exp Immunol. 2006 Nov;146(2):218-25. http://dx.doi.org/10.1111/j.13652249.2006.03200.x. PMid:17034573.

40. Türkoğlu O, Eren G, Emingil G, Azarsız E, Kutukculer N, Atilla G. Does smoking affect gingival crevicular fluid LL-37 levels following non-surgical periodontal treatment in chronic periodontitis? Arch Oral Biol. 2016 Jan;61:98-105. http://dx.doi.org/10.1016/j.archoralbio.2015.10.018. PMid:26547698.

41. Davidopoulou S, Diza E, Sakellari D, Menexes G, Kalfas S. Salivary concentration of free LL-37 in edentulism, chronic periodontitis and healthy periodontium. Arch Oral Biol. 2013 Aug;58(8):930-4. http://dx.doi.org/10.1016/j.archoralbio.2013.01.003. PMid:23778112.

42. Ertugrul AS, Sahin H, Dikilitas A, Alpaslan NZ, Bozoğlan A, Tekin Y. Gingival crevicular fluid levels of human beta-defensin-2 and cathelicidin in smoker and non-smoker patients: a cross-sectional study. J Periodontal Res. 2014 Jun;49(3):282-9. http://dx.doi.org/10.1111/jre.12105. PMid:23721053.

\section{CONFLICTS OF INTERESTS}

The authors declare no conflicts of interest.

\section{${ }^{*}$ CORRESPONDING AUTHOR}

Leticia Helena Theodoro, UNESP - Universidade Estadual Paulista, Faculdade de Odontologia de Araçatuba, Departamento de Diagnóstico e Cirurgia, Disciplina de Periodontia, Rua José Bonifácio, 1193, 16015-050 Araçatuba - SP, Brasil, e-mail: leticia.theodoro@unesp.br 